\title{
LA CONDENA CONDICIONAL
}

1. Introducción. 2. Antecedentes legislativos nacionales. 3. Naturaleza juridica de la condena condicional. 4. Denominación dada a la institución. 5. Fines de la condena condicional. 6. Fuente legal. 7. Condiciones para su concesión: a) condena a pena de prisión no mayor de seis meses. 8. Fijación de la pena y concesión de la condena condicional. 9. Pena de prisión compurgada total o parcialmente y condena condicional. 10. b) pena de multa. 11. Condena condicional en caso de penas conjuntas de prisión y de multa. 12. Pena de prisión sustíutiva de multa y condena condicional. 13. Penas accesorias. 14. Criterio admitido en la ley 9014. 15. c) primera condena nacional o extranjera. 16. Amnistía e indulto. 17. Delincuentes primarios y ocasionales. 18. d) pronóstico favorable sobre el futuro comportamiento del condenado. 19. Arbitrio judicial en la concesión de la condena condicional. 20. e) período de prueba: reglas de buena conducta. 21. Duración del período de prueba. 22. Revocación en caso de violación de las reglas de buena conducta. 23. Condena condicional y "Probation". 24. Reparación civil. 25. Revocación en caso de comisión de un nuevo delito. 26. Efectos de la revocación. 27. Concurso real retrospectivo. 28. Buen comportamiento durante el periodo de prueba. 29. Conclusión.

\section{Introducción}

En la doctrina y legislación extranjeras ha existido desde hace muchos años, una constante preocupación en torno a los problemas que presenta la frecuente aplicación de penas privativas de libertad de corta duración. Esto ha dado lugar a la creación de nuevas técnicas en el modo de ejecutarlas, a la admisión de nuevos medios para reemplazarlas o al perfeccionamiento de aquellos medios tradicionalmente utilizados. Entre estos últimos, se encuentra la condena condi- cional. Por esto, nos ha parecido interesante presentar la manera en que fle concebida por nuestro legislador,cómo fue modificada posteriormente y cómo ha sido comprendida y aplicada por nuestros jueces.

La escasa bibliografía nacional sobre esta institución nos ha llevado a consultar las fuentes doctrinarias extranjeras. La referencia constante a la legislación extranjera, la consideramos indispensable por estimar que el método comparativo permite preparar y favorecer toda reforma, mostrándonos las posibilidades de realizarla y la experiencia adquirida en otras latitudes.

La falta casi total de estadísticas nos ha imposibilitado comprobar el exacto funcionamiento de la condena condicional en nuestro medio. Las pocas y parciales referencias que sobre este aspecto hacemos en las páginas que siguen son el resultado de una labor de investigación en las mesas de partes de los tribunales y juzgados.

Debemos señalar, finalmente, que no pretendemos n! un tratamiento exhaustivo a todas las cuestiones relacionadas con la condena condicional, ni haber dado solución a todos los problemas de interpretación y aplicación. Lo único que buscamos es destacar esta institución, sobre todo en estos momentos en que se proyecta reformar nuestro Código Penal.

\section{Antecedentes legislativos nacionales}

En ninguno de los proyectos elaborados para modificar o reemplazar el Código Penal de 1863, se consideró a la condena condicional. Cuando se elabora el proyecto de $1900-1902$, ya se habian aprobado las leyes belga (1888) y francesa (1891), sin embargo, debido a la fuerte influencia española, no se intentó incorporar esta nueva institución, tan en boga en aquella época. Sólo en el proyecto Maúrtua de 1916 se establecen normas para regular la condena condicional. El 
autor las elabora insp:rándose en los trabajos del legislador suizo, que tendian a la unificación de su legislación penal. Dichas disposiciones, con algunas modificaciones, devienen en 1924, en los artículos 53 y siguientes del Código penal.

El 23 de noviembre de 1939, por iniciativa de la Corte Suprema, se modifican las disposiciones del Código penal que regulan la condena condicional; pero en la misma fecha se promulga el nuevo Código de procedimientos penales, cuyo artículo 286 trata, también, de la condena condicional. Este código entró en vigor el 18 de marzo de 1940. Esta sucesión de disposiciones legales ha creado cierta confusión en torno a la institución que estudiamos.

\section{Naturaleza juridica de la condena condicional}

Antes de iniciar el estudio de la manera como la condena condicional ha sido regulada en nuestra legislación, nos parece conveniente analizar el problema de la naturaleza juridica de esta institución. La doctrina nacional no se ha ocupado con la debida amplitud de este tema y la jurisprudencia no es 10 suficientemente clara.

En la doctrina extranjera, especialmente de habla alemana, no hay un criterio unánime al respecto. Alguros juristas consideran que la condena condicional es una especial clase de pena (1); otros estiman que es un modo de ejecutar determinadas penas privativas de libertad (2); algunos otros opinan que se trata de una medida de corrección (3); una minoría defien-

1. Hans Welzel dice: "La suspensión a prueba de la pena contiene una auténtica sanción”, Derecho penal alemán, Parte general, $11^{\text {a }}$ edición, Santiago de Chile 1970 , p. 345; Ricardo Núñez, siguiendo a Herrera, afirma: "Es una verdadera pena de advertencia o de intimidación, fruto del principio de la individualización de la pena", Derecho penal argentino, $2^{\text {a }}$ edición, Buenos Aires 1965, T. II, p. 523; Fontán Ballestra expresa: "Es una clase de pena destinada a ejercer una acción preventiva y moral sobre el condenado", Tratado de Derecho penal, Buenos Aires 1966, T. III, p. 396.

2. Lackner-Massen, Strafgesetzbuch, $7^{\text {a }}$ edición, 1972 , p. 51: Schönke-Schröder, Strafgesetzbuch, 15 $5^{\text {a }}$ edición, München der Vollstreckung einer Sanktion", Der bedingte Strafvollzug nach dem Bundes gesetz von 18 . März 1971, in Revue Pénale Suisse, Berna 1973, p. 56. 3. E. Schmidt, Reform des Strafvollzugs, in Zeitschrift für die gesamte Strafrechtswissenschaft 1952, p. 1; Thormann- von Overbeck expresan: "Massregel stra- de el criterio de que se trata de un medio de reacción penal independienie de las penas y de las medidas de seguridad (4). Además, es de señalar que hay autores que la consideran sea como un medio de individualización de la pena (5) o como un sucedáneo de las perias privativas de libertad (6).

Del estudio de las diversas opiniones vertidas en torno de este problema, podemos afirmar que todo enfoque unilateral fracasará, por cuanto la condena condicional, como ya lo señalara Molinario en 1915, "no es una institución unilateral por su objeto". Lejos de ahí, ella realiza a un mismo tiempo funciones de indole diversa, debiendo, pues, considerársela en el sistema general del Derecho penal, como un organismo de compleja trama y multiplicada eficacia (7). Es decir, que no se podrá comprender la condena condicional si se parte sólo desde un punto de vista represivo o sólo desde un punto de vista preventivo; ya que sus fires son múltiples.

Es de tener en cuenta, también, que los juristas no martienen, en si mayoria, puntos de vista unilaterales; sino que, expresa o tácitamente, destacan un aspecto de esta institución considerándolo como el más importante. Por esto, podríamos decir con Maurach que la solución debe ser un compromiso entre las opiniones extremas. Según este autor, la condena condicioral es, materialmente, una medida correctiva que comporta la cooperación del autor, $y$, formalmente, una particular pena privativa de liberład (aunque no ejecutable condicionalmente) (8). Recurriendo a un

frechtlicher Art", Das schweizerische Strafgesetzbuch, Zürich 1940, T. I, p. 168; y Reinhart Maurach afirma: "Massregel in Gewande einer Freiheitsstrafe", Deutsches Strafrecht, 4 a edición, Karlsruhe 1971, p. 866. 4. Jürgen Baumimn manifiesta: "Sie (die Strafaussetzung) ist eine Rechtsfolge besonderer Art, wenn man will eine "dritte Spur im Strafrecht", Strafrecht, 5? edición, Tübingen 1968; of. H. H. Jescheck, Lehrbuch des Strafrechts, parte general, Berlín 1969, p. 547.

5. R. Saleilles, L'individualisation de la peine, Paris 1898 , p. $190 \mathrm{y}$ s.

6. E. Zürcher, Exposé de motifs de l'avant-projet d' avril 1998, Berna 1914, p. 148; P. Logoz, Commentaires du Code pénal suisse, parte general, Neuchâtel-Paris 1939, p. 178; José Peco, Proyecto de Código penal argentino - Exposición de motivos, La Plata 1942, p. 185. 7. La condena de ejecución condicional, en Jurisprudencia Argentina, Buenos Aires 1925, p. 72.

8. Deutsches Strafrec ht, parte general, p. 866. 
método parecido, Lackner y Massen al comentar el Código penal alemán, estiman que la condena condicional, de acuerdo a las disposiciones legales, no es una pena ni una medida de seguridad, sino tan sólo una mcdalidad de ejecución de la pena, pero que si se tiene en cuenta sus fines, debe ser concebida como un medio efectivo para lograr la resocialización del condenado (9).

Existe unanimidad en la doctrina, por el contrario, en el rechazo a la opinión que concibe la condena condicional como una gracia, como una medida de indulgencia o de clemencia (10).

En sus decisiones, la Corte Suprema concibe a la condera condicional, en primer lugar, como un beneficio (11) que debe ser concedido al delincuente primario, no peligroso, y cuando la pena a imponerse sea exigua (12). Este criterio está determinado por el hecho de que el Supremo tribunal subraya, de manera particular, el aspecto represivo (punitivo) de nuestro sistema penal. De ahi que califique a una pena de prisión de seis meses, impuesta condicionalmente, de

\section{Strafgesetzbuch, p. 50 y 51 .}

10. Esta concepción ha sido sostenida, en Francia, por Donnedieu de Vabre, quien afirma: "la suspensión de la cjecución de la pena es una medida de indulgencia que el juez tiene la facultad de ordenar cuando condena a un delincuente primario", Traité de droit criminel et de législation pénale comparée, $3^{\text {a }}$ edición, Paris 1947, p. 518. Entre nosotros, Gómez de la Torre sostuvo que la condena condicional es, en realidad, el perdón de la primera falta cometida por una persona en circunstancias tales, y cuyos antecedentes hacen presumir que se trata de un delincuente ocasional que entrará fácilmente en el camino del arrepentimiento, de la enmienda y la readaptación. Llegando a afirmar que "la condena condicional es, pues, el olvido del primer delito...", La condena condicional, in Revista Universitaria, Lima 1902, p. 41.

11. El texto original del artículo 53 , in fine, se refería al "beneficio de (la) suspensión condicional". La exposición de motivos del anteproyecto del código de procedimientos penales se refiere, igualmente, a la condena condicional como un "beneficio", ver: Revista del Foro, Lima 1939, p. 301.

12. Ver ejecutorias del 21 de mayo de 1932, del 7 de octubre de 1933 y del 23 de abril de 1953 y el oficio de la Segunda Sala de la Corte Suprema dirigido a la Corte Superior de Arequipa, in Revista de los tribunales 1932, p. 109, Anales Judiciales 1933, p. 265, Revista de Jurisprudencia Peruana 1953, p. 989 y Anales Judiciales 1935 , p. 419 , respectivamente. "castigo insignificante", "hasta cierto punto irrisorio" (13). Por eso, igualmente, considera que si bien "el artículo 148 del Código penal (referente a menores de 21 años y mayores de 18) favorezca al encausado, no quiere decir que se vaya hasta la impunidad. Puede rebajarse la pena prudencialmente, pero no al extremo de conceder el beneficio de la Condena condicional" (14). Esta manera de comprender la condena condicional es expresada por la misma Corte Suprema en los considerandos de su proyecto de ley modificatorio del Código penal, en la parte relativa a la condena y liberación condicional. Dice textualmente: "la condena condicional deja impune el delito y sólo es aceptable en circunstancias muy excepcionales" (15).

Sin embargo, es de destacar la Ejecutoria del 21 de julio de 1951, en la que -contradiciendo al Fiscal que afirmaba "que la condicionalidad importa la impunidad" - Ia Corte Suprema afirma: "que no pueden considerarse impunes los hechos delictuosos que son objeto de una condena condicional, impuesta, en cada caso, ... que el carácter punitivo de esta sanción aplicada por los códigos modernos para sustituir las prisiones cortas, es incuestionable..." (16). Después de esta aclaración resulta incongruente que la misma Corte Suprema continúe refiriéndose a la condena condicional como si se tratara de un mero beneficio. Posteriormente veremos como esta concepción influye negativamente en la comprensión y aplicación de las disposiciones legales referentes a la condena condicional.

\section{Denominación dada a la institución}

En doctrina se ha discutido mucho sobre el nombre dado a esta institución. Se critica, por ejemplo, que la denominación generalmente usada de "condena condicional" no es correcta, pues, no es la condena la afectada por la condición, sino la ejecución de la pena. La justeza de esta observación sólo será determinada tenténdo en cuenta la manera como el legislador ha regulado esta institución. Así, tal crítica es acertada si se considera la manera como está configurada en los primeros proyectos suizos, en la ley belga de 1888, en el código penal italiano de 1930 o

13. Ejecutoria del 26 de octubre de 1942, in Anales Judiciales 1942, p. 327.

14. Ejecutoria del 25 de julio de 1951, in Revista de Jurisprudencia Peruana 1951, p. 1328.

15. Anales Judiciales 1939, p. 343.

16. Ejecutoria del 21 de julio de 1951, in Revista del Foro 1951, p. 794. 
en el texto original del Código penal suizo de 1940. Por el contrario, creemos que, según nuestra legislación, la denominación "condena condicional", no es del todo errónea; por cuanto, en el articulo 55 nuestro legislador ha sometido a una "condición resolutoria" a la condena que se impone al delincuente. Sabemos que esta opinion ha sido frecuentemente criticada por destacados juristas. Nos basta señalar a Soler y Núñez en la Argentina, autores que comentan disposiciones muy parecidas a las de nuestra legislación sobre la condena condicional (17).

En defensa del criterio sostenido por nosotros está el hecho de que autores como Logoz y Graven, al estudiar el Código penal helvético, consideran que el legislador de su país escoge, en definitiva, la noción de "remisión a la ejecución de la pena", sólo al aprobar el texto definitivo del Código. Por el contrario, la segında comisión de expertos admitió, al elaborar el proyecto de 1918, que fue la base para las discusiones parlamentarias, la condena condicional (18). En este proyecto, los expertos suizos reprodujeron, en buena cuenta, las disposiciones de los anteproyectos de 1915 $y$ de 1916. $Y$ es el caso de que el modelo seguido por nuestro legislador al redactar las normas del Código penal sobre condena condicional fueron, precisamente, estos antecedentes legislativos helvéticos. A su vez, el legislador suizo se inspiró en el modelo francés. La fuente de la disposición aprobada por las Cámaras legislativas suizas fue la legislación belga (19).

\section{Fines de la condena condicional}

El legislador ha considerado, casi siempre, como fin primordial de la condena condicional, la lucha contra las consecuencias dañinas producidas por la aplicación efectiva de las penas privativas de libertad de corta duración (20). Por esto es de suponer que al

17. Es de recordar que la doctrina argentina no es unánime al respecto, discrepan Allende y Gatti; ver: Posibilidad de aplicar más de una vez la condena condicional, in La Ley, T. 55, Buenos Aires, p. 237.

18. P. Logoz, Commentaires, parte general, p. 177 178; Jean Graven, Le sens du sursis conditionnel et son developpement, in Revue Pénal suisse 1954, p. 261. 19. J. Graven, Revue Pénale Suisse 1954, p. 274.

20. En la exposición de motivos, el legislador expresaba: "Entre los sistemas creados con tanta felicidad para sustituir las penas de prisión de corta duración, el proyecto ha adoptado el sistema franco-belga, que consiste en suspender la ejecución de la condena, en lugar admitir, también, su aplicación a la pena de multa, nuestro legislador lo hizo considerando que esta pena puede siempre convertirse en prisión.

Por el contrario, parece no haber sido esta la preocupación principal que tuvo el legislador al dictar la ley 9014, en base al proyecto elaborado por la Corte Suprema. De los considerandos y del articulado de esta ley puede deducirse que la preocupación fundamental fue la de restringir la aplicación de la condena condicional a un número limitado de casos, para evitar el debilitamiento de la represión penal. En la exposición de motivos de dicha ley ce afirmaba, por ejemplo, que "Por excepción, puede admitirse esa medida (la condena condicional), si la condena versa sobre delitos cometidos por negligencia, porque no entrañan intención delictuosa, pero de ninguna manera como una regla general', y en los considerandos, en velada referencia a las penas privativas de libertad de corta duración, se decia que bastan "las leyes sobre el indulto para conciliar las exigencias de la justicia con los efectos de la condena" (21).

La Corte Suprema, sin embargo, no ha dejado de señalar, en algunos de sus fallos, que la condena condicional es una especie de aviso dado al delincuente primario. Aviso que estima suficiente para impedir la reincidencia. Así, en su ejecutoria del 19 de diciembre de 1941, reproduce los fundamentos del dictamen del Fiscal, quien expresaba que las circunstancias del acto delictuoso "justifican la pena impuesta... y ... que su suspensión es legal y justa, ya que con la simple condena debe presumirse que el sentenciado no volverá a delinquir" (22). En la ejecutoria del 21 de julio de 1951 va más lejos al afirmar que "sólo se suspende su aplicación con el objeto de log:ar la reiorma def delincuente susceptible de enmienda fuera del penal. .." (23).

del sistema americano que suspende la pronunciación de ésta", Código penal, edición oficial, Lima 1939, p. 169.

21. Anales Judiciales 1939 , p. 344.

Ejecutoria del 19 de diciembre de 1941, in Revista de los Tribunales 1942, p. 25.

22. Ejecutoria del 21 de julio de 1951, in Revista del Foro 1951, p. 794.

23. Refiriéndose la institución de la condena condicional, como lo hemos visto al estudiar su naturaleza, al contenido material de la relación punitiva, se desprende que pertenece fundamentalmente al Derecho penal 


\section{Fuente legai.}

Según el texto original del arículo 53, párrafo 19, del Código penal, la condena condicional consiste en la suspensión de la ejecución de la pena bajo la condición de que el condenado se porte bien durante un periodo de prueba. Esie mismo criterio es mantenido por el legislador en la ley 9014 del 23 de noviembre de 1939 y en el artículo 286 del Código de procedimientos penales. No se trata, pues, del sistema de la "Probation" (angloamericana), sino del sistema adoptado en el continante europeo a partir de las leyes belga de 1888 y francesa de 1891.

Como ya lo hemos dicho anteriormente, la fuente legal de las disposiciones de nuestro Código sobre la condena condicional son los proyectos suizos. Al redaciar el proyecio de 1916, el legislador tuvo como modelo las disposiciones del anteproyecto suizo de agosto de 1915; las modificaciones hechas a dichas disposiciones en el texto definitivo de nuestro Código han sido inspiradas por el proyecto helvético de 1918.

El aríiculo 13 de la ley 90 i4 que modificó, temporalmente, el artículo 53 de nuestro Código, no tiene precedente, en cuanto a nuestro conocimiento, en la legislación extranjera.

El artículo 286 del Código de procedimientos penales, que derogó la disposición antes indicada, puede considerarse de origen francés. Esta nueva reforma constituye, en buena cuenta, un retorno al texto original del artículo 53.

\section{Condiciones para su concesión: a) condena a pena de prisión no mayor de seis meses}

De acuerdo al articulo 286 del Código de procedimientos penales, el juez puede suspender la ejecución de la pena de prisión que no exceda de seis meses y de la pena de multa, sin importar su monto.

El iegislador justif́ica su decisión de fijar en seis meses la extensión de la pena susceptible de ser suspendida, manifestando que "el tiempo mínimo adoptado para la pena de prisión se explica fácilmente por

sustantivo y no al procesal; cf. Vicenzo Manzini, Tratatto di Diritto Penale italiano - Secondo il Codice di 1930, Torino 1934. T. III. T. V, p., 539. En contra: D. García Rada, ver su voto singular en ocasión de la ejecutoria rel 13 de mayo de 1959, in Revista de Jurisprudencia Peruana 1959. p. 1026. tratarse de un resorte (la condena condicional) enteramente nuevo cuya aplicación demanda suma prudencia"' (24).

Este límite puede ser considerado muy bajo. Nuestro legislador debió, por lo menos, seguir de cerca el modelo helvético que fijaba un máximo de un año (25). Tres afíos antes de aparecer nuestro Código, el legislador argentino habia establecido que la condena condicional podía ser concedida hasta cuando la pena privativa de libertad fuere de dos años. El límite de seis meses, escogido por nuestro legislador, se revela insuficiente si se piensa que él mismo ha considerado, en el Código de procedimientos penales, que la liberación provisional (cuya finalidad es, igualmenie, evitar el ingreso del delincuente en prisión) se concederá a los inculpados de delito sancionado con no más de dos años como extremo máximo de la pena. Podría suceder, por ejemplo, que el autor de un delito de seducción (art. 201, pena no mayor de dos años de prisión) sea puesto en libertad provisional por el juez instructor, a fin de evitarle los efectos nocivos del encarcelamienio; pero al dictar sentencia, le imponga un año de prisión efectiva, pena que considera adecuada a la culpabilidad del agente. Los fines de la liberiad provisional se verian frustrados. Para evitar esto, nuestros jueces imponen penas de seis meses, aún cuando no correspondan a la gravedad del acio y de la culpabilidad del agente, y poder, de esta manera, conceder la condena condicional.

La tendencia legislativa en los últimos años, se orienta hacia la concesión de la condena condicional a penas de mayor duración. En Alemania, se prevé para penas no mayores de un año $y$, en condiciones especiales, para penas de hásta dos años (26); en Suecia, se concede para toda pena de reclusión, cuyo máximo puede ser hasta de diez años (27); en Bélgica, es posible otorgarla hasta por penas no mayores de tres años (28); en Suiza, la ley de reforma del 18 de

24. Código penal, edición oficial, p. 169.

25. Cf. Manuel G. Abastos, El delincuente en el Código Maúrtua, in Revista de Derecho y Ciencias Políticas, Lima, 1938, p. 311.

26. Artículo 23, párrafos 1 y 2 , texto de setiembre de 1969, in Bundesgesetzblatt, Bonn 1969.

27. Capítulo XXVII, artículo 2, del Código penal sueco, texto de 1965, in Información Jurídica, $\mathrm{N}^{0}$ 294-295, Madrid 1967.

28. Artículo 9 de la ley del 29 de jumio de 1964, in Pasinomie, Bruselas 1964, p. 858 . 
marzo de 1971 aumenta de un año a dieciocho meses la duración de las penas cuya ejecución puede ser suspendida condicionalmente (29); en Italia, el proyecto Gonella mantiene el límite de un año establecido en el Código, pero lo aumenta en caso de multa a dieciocho meses (30); en el Brasil y la Argentina se mantiener los límites de dos años (31); en nuestro país, el artículo 53 del proyecto de $1972 \mathrm{fija}$, igualmente, dicho límíe en dos años.

\section{Fijación de la pena y concesión de la condena condicional}

El agente puede haberse hecho merecedor de esta pena por la ejecución de cualquier delito o falta que sea reprimido con pena no mayor de seis meses de prisión o cuando siendo superior a este limite, la existencia de determinadas circunstancias, por ejemplo, un error de hecho o de derecho no culpable (art. 87), una eximente incompleta de pena (art. 90), permite al juez imponer una sanción de tal magnitud.

Se trata, pues, de la pena fijada en la sentencia de acuerdo a la culpabilidad y peligrosidad del agente (art. 51). De manera que la naturaleza de la acción, el tiempo y lugar de la perpetración, los medios usados, el modo de ejecución, en buena cuenta, el tipo y la gravedad de la infracción no son determinantes para la concesión de la condena condicional. Estos factores serán considerados, por el juez, al momento de individualizar la pena. Con razón afirmaba Angel Gustavo Cornejo: "la importancia o naturaleza del delito no entra en consideración para otorgar la condera condicional"' (32).

29. Artículo 41, No 1, párrafo $1^{\circ}$; ver: José Ifurtado, La reforma parcial del Código penal suizo (Ley penal del 18 de marzo de 1971), in Derecho, Lima 1972, p. $103 \mathrm{y} \mathrm{s}$.

30. Artículo 42. El límite se duplica en caso de delincuentes que han cumplidlo 70 años y es de 3 años en caso de menores de 18 anos; ver: Senato della Repubblica, V Legislatura, N? 351, Roma 1968.

31. Artículo 71 del Código penal brasileño de 1969 , in Revista de informaçao legislativa, Senado Federal, año VI, No 24, y artículo 26 del Código penal argentino, modificado por ley $N^{\circ} 17567$ del 19 de julio de 1968. 32. Comentarios al nuevo Código penal, Lima 1926, p. 187; cf. Brums quien dice: "Erst nach Fixierung der schuldangemessencn Strafe ist die Frage der Strafaussstzung zu prifen, beider es sich nach h. L. lediglich um eine Modifikation der Vollstreckung handelt...", Strafzumessungsrecht, Parte general, 1967, p. 31.
Nuestra jurisprudencia no distingue, correctamente, estas dos fases. La primera, en la que se determina la pena (art. 51), y, la segunda, en la que se tiene en cuenta la gravedad de la infracción. En muchos casos, como en los delitos culposos, las circunstancias fácticas no revelan, necesariamente, que el autor sea indigno de la condena condicional, $y$, por el contrario, un caso objetivamente leve ya puede constituir un indicio de que el agente tiende a cometer nuevos actos delictuosos.

En reiteradas oportunidades la Corte Suprema, ya sea para conceder o denegar la condena condicional, recurre a la "naturaleza del delito" o a la necesidad de "sancionar hechos de tal naturaleza". Ver, por ejemplo, ejecutorias del 29 de abril de 1941, del 19 de diciembre de 1941, del 5 de mayo de 1944 y del 23 de octubre de 1952 (33). En las dos últimas se dice, expresamente, "que la forma y circunstancias en que se ha cometido el delito excluye el beneficio de la suspensión de la pena" y quie es "necesario sancionar hechos de esta naiuraleza (accidente de tránsito que provoca tres muertos y dos heridos) que se repiien con frecuencia'. Aquí predomina una razón de prevención general, directamente vinculada al tipo de infracción. Lo mismo sucede en la ejecutoria del 26 de octubre de 1952, en la que la Corte Suprema declara haber nilidad en la sentencia recurrida que imponia al acusado la pena de seis meses de prisión condicional, y reformándola le impuso un año de prisión, considerando, de acuerdo con el dictamen del Fiscal, que "el abigeato es un delito que se está repitiendo con frecuencia; (y) debe ser reprimido en forma seria (sic)..." (34). En nuestra opinión, estos fallos revelan de parte de sus autores una equivocada concepción de la naturaleza y fines de la condena condicional (35).

\section{Pena de prissión compurgada total o parcialmente y condena condicional}

No procede otorgar la condena condicional por el resto de la pena (no mayor de seis meses) que debe

33. Dichas ejecutorias han sicto publicadas en Anales Judiciales 1935, p. 419, Revista del Foro 1941, p. 383, Revista de los Tribumales 1942, p. 25, Anales Judiciales 1944, p. 95, Revista de Jurisprudencia Peruana 1952 , p. 2983.

34. Ejecutoria del 26 de octubre de 1942, en Anales Judiciales 1942, P. 327.

35. Ver Supra N 3 y 5 . 
aún cumplir el condenado, después de ser descontada la carceleria sufrida durante el proceso. Se ha discutido, con cierta frecuencia, si es posible conceder la condena condicional por una pena de prisión no mayor de seis meses y al mismo tiempo dar por compurgada uria parte de esta sanción. En una de sus resoluciones, la Corte Suprema ha respondido, desestimando la opinićn favorable del Fiscal. Considera que "es inadmisible la aplicación conjunta de una condena condicional y una pena de prisión (efectiva) aunque sea compurgada ya que por su naturaleza y consecuencias se excluyen..." (36). Se trataba de una mujer sancionada por el Tribunal Correccional a tres meses de prisión compurgada en un mes y veinte días y suspendida condicionalmente en el resto. La Corte Suprema declara haber nulidad en la sentencia, por las razones ya indicadas, y reformándola le impone un mes de prisión, compurgada con la carceleria sufrida. Con este mismo criterio, es evidente, que no es posible admitir la condena condicional en caso de que la pena impuesta se dé por compurgada totalmente.

Esta concepción de nuestra jurisprudencia es demasiado formalista y no tiene en cuenta los fines de la institución. En la doctrina y jurisprudencia extranje$\mathrm{ra}$, las soluciones adoptadas en torno a este problema ro son concordes. Asi, por ejemplo, la Corte de Casación italiana considera que el "beneficio es aplicable aún cuando la pena ha sido completamente cumplida en detención preventiva" (37). El Tribunal federal suizo, en reiteradas decisiones, adopta la misma solución, por considerar que aún en tal caso la condena condicional es ventajosa para el delincuente y para la sociedad ( $\$ 8)$; el Tribunal alemán considera inadmisible que se conceda por tan sólo una parte de la pena (39), pero considera que no es excluida por la

36. Ejecutoria del 13 de octubre de 1947, in Revista de Jurisprudencia Peruana 1948, p. 565.

37. Cass. Sez. I, 22 gennaio 1962, Bulla, Cass, pen. Mass, ann. 1962, 640, m. 1158, citada por Guissepe Lattenzi, I Codisi Penali, Milano 1964, p. 226.

38. Bundesgerichtsentscheid 195581 IV 210; 194369 IV 151.

39. Entscheidungen des Bundesgerichtshofes in Strafsachen 6, 163. El artículo 23, párrafo 4, ab initio, del Código penal alemán reformado dice: "Die Strafaussetzung kann nicht auf eien Teil der Strafe beschränkt werden". Pero, esta misma disposición estatuye que la condena condicional no es excluida por la imputación de la detención preventiva o de otro tipo de privación de libertad. Expresamente dispone: "Sie wird durch imputación de la detención preventiva o de otro tipo de privación de la libertad. Por el contrario, la jurlsprudencia francesa sostiene el criterio opuesto (40).

\section{0. b) pena de multa}

La pena de multa consiste en la imposición al delincuente, por parte del juez, de la obligación de pagar una cieria cantidad de dinero, en concepto de retribución del delito cometido. En la legislación penal moderna, esta pena ha desempeñado un rol importante en la lucha contra las penas privativas de libertad de corta duración (41).

En el artículo 20 de nuestro Código penal, la multa ha sido regulada conforme al sistema sueco del profesor Thyrén. Según este sistema, el monto de la multa resulta de multiplicar el número de días-multa (unidad de medida artificial) por el monto de cada día-multa (fijado por el juez de acuerdo a la capacidad económica del delincuente) (42). El objetivo principal es que el condenado cumpla con hacer efectiva la multa. Para esto, el juez fijará un plazo prudencial para el pago y podrá, también, autorizar a realizarlo por cuotas, "haciéndolo compatible con las necesidades del condenado y de su familia" (43).

Sólo en el caso de que el condenado no pague la multa en el plazo fijado o sea insolvente, la multa se convertirá en prisión a razón de un día por cada sol. La duración de la prisión no podrá exceder de tres meses (art. 21). Esta conversión representa, especialmente, en caso de insolvencia del condenado, "uno de los mayores peligros de injusticia de esta pena" (44).

eine Anrechnung von Untersuchungshaft oder einer anderen Freiheitenziehung nicht ausgeschlossen", in Bundesgesetsblatt 1969.

40. Lyon, 20 février 1893, Gaz. Pal. 1893, II 547, citada por Bouzat et Pinatel, Traité de droit pénal et criminologie, $2^{a}$ edición, Droit pénal géneral, Paris 1970 , p. 636.

41. Schmelck et Picca, Pénologie et droit pénitentiaire, Paris 1967, p. 109.

42. Ancel - Strahal, Le droit pénal des pays scandinaves, Paris 1969, p. 118 y s. Nuestro Código en su artículo 20 , in fine, estatuye que si el condenado no tiene bienes, empleo o industria, no ganare salario, se considerará como renta el salario normal.

43. Artículo 23 del Código penal; ver exposición de motivos en Código penal edición oficial, 1939, p. 166167.

44. Sebastián Soler, Derecho Penal argentino, Buenos Aires 1963, T. II, p. 391. 
Pero aún cuando la conversión ha sido ordenada, es posible evitar la prisión. De un lado, el condenado puede, en cualquier momento, hacer cesar su encarcelamiento pagando la multa, deducida la parte correspondiente de la prisión suírida (art. 22); y, de otro lado, el condenado puede pedir que se reemplace la prisión sustitutiva de la multa por la prestación de un trabajo determinado en una obra del Estado o de insfituciones de utilidad pública, en razón de un día de trabajo por cada dia de prisión (art. 24) (45).

Teniendo en consideración las medidas previstas por nuestro legislador para el cumplimiento de la pena de multa, podemos afirmar que su conversión en una pena de prisión tendrá lugar, sólo, en caso de insolvencla o de incumplimiento de pago por mala voluntad del condenado. En el segundo caso de los nombrados, el encarcelamiento del condenado que no quiere pagar la multa sería justa, si bien podría discutirse sobre su oportunidad. En el primer caso, por el contrario, el encarcelamiento del condenado insolvente parece como un castigo a su falta de capacidad económica. Esto ha dado pie a numerosas críticas contra la pena de multa. Esta posibilidad parece que fue tomada en cuenta por nuestro legislador para admitir la condena condicional en caso de que se imponga la pena de multa. Al respecto, el texto original del artícu10 53, in fine, estatuía: "La pena de multa podrá ser también objeto del beneficio de suspensión condicional" (46). El artículo 286 del Código de procedimienios penales la enumera en primer lugar. Esta solución ya habia sido adoptada por la ley belga de 1888, la ley francesa de 1891, el Código penal argentino de 1921, el Código penal italiano de 1940 (47). Doctrina-

45. A nuestro conocimiento, no se ha aplicado este sunbstituto de la prisión que reemplaza a la multa impaga. Este sistema, admitido últimamente en el contraproyecto alemán de 1966, ha sido criticado, sobre todo, en relación a las posibilidades prácticas de ejecución. Sus defensores han respondido que, ciertamente, el Estido deberá crear los nuevos organismos que permitirán la aplicación de tal disposición y que modificaciones institucionales de esta envergadura están vinculadas a toda reforma en profundidad. Ver al respecto: Peter Noll, Le contre-projet d'un code pénal allemand, in Revue de Droit pénal et de Criminologie 1969, p. 757 , nota 11 y la bibliografía citada.

46. Reproduce el último párrafo del artículo $40 \mathrm{del}$ Proyecto peruano de 1916, que parece inspirado en la legislación francesa.

47. El proyecto Gonella mantiene el mismo criterio, riamente, muchos no aprueban este criterio por estimar que la ejecución de una pena de multa no expone al condenado a los peligros propios de las penas privativas de libertad de corta duración. Este es el criterio que primó, por ejemplo, en la segunda gran comisión redactora del Código penal suizo, que no aceptó una propuesta de Delaquis y Studer para extender, siguiendo el ejemplo francés, la condena condicional a la pena de multa (48). Este rechazo se comprende por cuanto la condena condicional surge como medio de lucha ideal para combatir los efectos nocivos de las penas privativas de libertad de corta duración. Hacia este fin, a nuestro entender, se orientaron tanto el legislador francés como el nuestro, al exlender la aplicación de la condena condicional a la multa. Esta amplitud del campo de aplicación favorece el aspecto preventivo, autoreeducador, do la condena condicional.

A.lgunas legislaciones extranjeras contienen una solución intermedia, admiten que la condena condicional procede sólo cuando la pena de multa se sustituya por una pena privativa de libertad. Es el caso del Código penal español, artículo 93 (49); entre los proyectos cabe indicar el venezolano de 1967, artículo

pero señala que convertida (mentalmente) la multa a prisión (sola o conịunta a pena privativa de libertad) no sea mayor de 18 meses, en lugar de un año como lo hace el artículo 163 del Código vigente. Ver artículo 45. $\mathrm{N}^{\circ} 1$, del provecto de Código penal austriaco de 1969, in 706 der Beilagen zu den stenographischen Protokollen des Nationalrates XI G. P., Viena 1968.

48. Proces-Verbaux de la 2eme commission d'experts, Lucerne 1913, T. I, p. 421. En el Código penal brasileño de 1959, artículo 71, último párrafo, se excluye la suspensión condicional de la multa. El Código penal alemán, artículo $29, \mathrm{~N}^{\circ} 6$, disponía la remisión de la pena de multa, cuando el condenado, sin culpa, no la cancelaba. Esta disposición ha sido conservada en el texto reformado. El legislador argentino ha modificado, mediante Ley $\mathrm{N}^{\circ}$ 17567, el artículo 26 del Código penal, en el sentido de excluir para las penas de multa la aplicación de la condena condicional.

49. Artículo 93, No 3: "Que la pena consiste en privación de libertad, cuya duración no exceda de un año y esté impuesta como principal del delito o falta o como subsidiaria por insolvencia en caso de multa". Casi en idénticos términos estaba redactado el artículo 2, $N^{\circ}$ 3, de la ley española $N^{\circ} 233$ del 17 de marzo de 1958, que introdujo la condena condicional. Ver: Quintano Ripollés, Comentarios al Código Penal, Madrid 1966. 
98; y al peruano de 1972, que en el último párrafo del artículo 53, establece: "La pena de multa, en caso de insolvencia, podrá ser suspendida".

Nuestro legislador no hace depender del monto de la multa la concesión de la condena condicional.

La pena de multa, según nuestro Código penal, puede ser implesta como pena principal o como accesoria (art. 29). Como principal será impuesta cuando haya sido prevista, en la parte especial, como la única pena para el delito en particular (50), como pena alternativa junto a una pena de prisión (51) o como pena conjunta a una pena de prisión (52) o de inhabilitación (53). En su calidad de accesoria, la pena de multa será impuesta cuando el delito es cometido con fines de lucro o por codicia (art. 25) (54).

A pesar de la amplitud con que nuestro legislador recurre a la pena de multa, nuestros tribunales imponen en raras ocasiones esta sanción (55). De la mis-

50. No som más de diez y se trata de infracciones dolusas leves o culposas: artículos 183, 210, 234, 242, 243, $276,306,325,327,316$.

51. Existen veinticuatro casos; ejemplos: artículos 185, 209. 232, 268, 287, 292, 301.

52. Hay treintitrés casos, ejemplos: artículos 243, 248, $276,298,365,367$.

53. Se dan veintiún casos, ejemplos: artículos: 305 , 338. 347,360 .

54. Sobre penas accesorias y condena condicional, ver infra $N^{o}$ 13. El artículo 29 de nuestro Código penal parece no tener antecedentes legislativos nacionales o extranjeros. Sin embargo, es de considerar que la idea proviene de los anteproyectos suizos de 1915 y 1916 , fuentes legales del proyecto peruano de 1916. En dichos anterpoyectos se consideró a la multa, impuesta cilando el delincuente $l_{\text {ta }}$ actuado por codicia, entre las penas accesorias. Así el anteproyecto de 1915, bajo el rubro marginal de " 5 . Peines accesoires" consideró en el artículo 49 la "amende accessoire a une peine privative de liherté". En el proyecto de 1918, ya no figura bajo dicho rubro, sino en el correspondiente al de la multa; pero no se modifica el texto de la disposición: "Si le délinquant a agi par cupidité, le juge accessoirement à la peine privative de liberté, pourra le condamner à une amende" (art. 47).

Por esta misma razón, creemos, que José Peco consideró en su proyecto entre las penas accesorias la multa cuando el delito se comete por móvil de lucro (art. 49 de su proyecto). Ver su Proyecto de Código penal argentino, p. 153.

55. De una simple revisión de los cuadernos copiadores de sentencias de los Tribunales Correccionales, apa- ma manera proceden los jueces instructores en los casos que dictan sentencia.

En los raros casos en que imponen la pena de multa, nuestros jueces casi no hacen uso de la condena condicional (56).

En todos los casos en que la pena de multa es impuesta como principal (sola o conjuntamente con una pena privativa de libertad), el juez puede conceder la cordena condicional en virtud del artículo 286 del Código de procedimientos penales. Si fuere impuesta como accesoria, deberá invocarse el artículo 54 del Código penal que permite extender los efectos de la condena condicional, concedida para la pena principal, a las penas accesorias.

\section{Condena condicional en caso de penas conjuntas de prisión y multa}

Nuestra jurisprudencia no ha tenido ocasión de pronunciarse sobre la concesión de la condena condicional a un delincuente sancionado por una pena privativa de libertad y por una pena pecuniaria. De acuerdo a las disposiciones legales vigentes, es posible que el juez la otorgue en relación a las dos penas. Pero, ipodría otorgarla en relación a una y negarla en la otra? Sobre el particular, consideramos que estando cumplidas las condiciones exigidas por la ley y estimando el juez necesaria la concesión, sería poco lógico el negarla, supongamos sólo en relación a la pena privativa de libertad. Este criterio es admitido por la doctrina y jurisprudencia de Francia e Italia, países cuyas legislaciones admiten la condena condicional para la multa (57).

rece que del total de sentencias pronunciadas entre 1967 y $1971(15,287)$, en no más del uno por ciento se imponen multas.

56. Como referencia diremos que uno de nuestros colegas que ejerció el cargo de juez instructor suplente, en forma continuada durante tres años, no dictó más de diez sentencias imponiendo multas, de las cuales una sola condicionalmente.

57. Ver Bouzat et Pinatel, Traité de droit pénal et criminologie, p. 636. La Corte de Casación italiana ha resuelto que "en el caso de condena por un delito sancionable con pena privativa de libertad y con pena pecuniaria, es ilegítima la concesión del beneficio limitado sólo a la primera", Cass. 24 giguno 1948, Remo altri Giustizia Penale 1948, II, p. 598. Merece señalarse el caso del Código penal sueco que establece: "jinto a la condena condicional puede imponerse multa no mayor de 120 días-multa, aún cuando la ley no lo establezca, 
12. Pena de prisión sustitutiva de multa y condena condicional

De la manera como se ha regulado la multa y la condena condicional en nuestro ordenamiento legal, surge el problema de saber si seria posible suspender condicionalmente la pena de prisión que sustituye una pena de multa ro pagada por insolvencia. De "lege lata", no procede, ya que el artículo 286 del Código de procedimientos penales dice: "En los casos en que se dicte condena de multa o de prisión que no exceda de seis meses...". De "lege ferenda", cabría preguntarse si la concesión de la condena condicional no compensaria la injusticia debida a la desigualdad económica, de la cual el condenado no es culpable. Sin embargo, podría evitarse esta situación, al meinos parcialmente, no imponiendo la pena de multa cuando se conoce o se tiene razones fundadas para creer insolvente al delincuente (58).

\section{Penas accesorias}

Según el artículo 14 de la ley 9014 , cuyo texto reproduce casi literalmente el del artículo 54 del Código penal, la suspensión condicional de la ejecución de la pena principal puede ser extendida por el juez a la de las penas accesorias y a la de las incapacidades establecidas en la sentencia. De esta manera, el legislador resuelve, expresamente, un problema muy discutido en doctrina.

En doctrina se considera penas accesorias a aquéllas que siguen a una pena principal (sanción esencial) de la infracción. Cuando el juzgador impone una pena principal, a la cual el legislador ha vinculado una pena accesoria, ésta se aplica automáticamente, de pleno derecho, por ley, sin que haya necesidd de que el juez la pronuncie especialmente. El juez no puede, de otra parte, ordenar su no aplicación (59).

pəro si es que es necesaria para la reeducación del delincuente o para la prevención general" (art. 2, Capítulo XXVII).

58. En realidad, los delincuentes se reclutan en su gran mayoría entre los menos favorecidos económicamente; esto cxplicaría, también el porqué esta pena ha logrado poco éxito en nuestro medio.

59. Bouzat et Pinatel, Traité de droit pénal et criminologie, p. 324. El Código penal italiano define ambos tipos de penas de la siguiente manera: artículo 20 "Le pene principali sono inflitte dal giudice con sentenza di condanna; quelle accessorie conseguono di diritto alla condamna, come effetti penali di essa".
Sin embargo, es de destacar que esta clasificación precisa de la doctrina no es, rigurosamente, admitida por el legislador. Este parece ser el caso en nuestra legislación. El artículo 29 de nuestro Código penal estatuye que las penas de multa e inhabilitación pueden ser impuestas como penas principales o como accesorias. La multa podrá ser considerada accesoria, sólo cuando el delito hubiera sido cometido con fines de lucro o por codicia. El artículo 25 establece que en esos casos, "el juez agregará una multa"; es decir que es necesario que la imporga expresamente el j:ez y éste no la podrá imponer en todos los casos que condene, por ejemplo, a pena privativa de la libertad. Respecto a la inhabilitación, el artículo 30, infine, declara expresamente: "Cuando fuere impuesta como accesoria de las penas privativas de la libertad, su tiempo comenzará a correr desde el día de la liberación definitiva del concienado" (60). Es decir, que ruestro legislador no ha considerado su aplicación automática, de pleno derecho. Si el juzgador omite declarar la inhabilitación posterior y su sentencia queda consentida, no podrá considerarse al condenado como inhabilitado. Nuestra jurisprudencia exige que en las condenas por infracciones cometidas con abuso del ejercicio de un mandato, cargo, empleo, profesión, negociación o arte, se imponga, taxativamente, la inhabilitación relativa, a pesar de que el artículo 36 establece que ésta "irá siempre anexa" a tales condenas (61).

Admitir que la noción de pena accesoria aceptada por nuestro legislador debe ser la sostenida por la docirina, nos conduciría a confusión en la interpretación de otras disposiciones del Código penal. Esto implicaría que la pena de prisión no admite pena accesoria alguna y que, por lo tanto, está demás el artículo 54 (Art. 14 de la ley 9014) que prevé la extensión de la suspensión condicional de la ejecución de la pena principal a la de las penas accesorias. Los miembros de la Comisión revisora del Código penal, que ha elaborado el proyecto de 1972, admiten que la prisión tiene accesorias, al disponer que "la suspensión condicional de la ejecución de la pena principal no se extenderá a las penas accesorias...". De esta manera, se seguiría la orientación del Código de procedimientos penales francés que en su articulo 736

60. Ver artículos 31,34 y 35 del Código penal.

61. Ejecutoria del 3 de mayo de 1945, in Anales Judiciales 1945 , p. 146. 
establece igual prohibición; en la América latina, el Código penal brasileño de 1969 contiene igual solución, por lo demás ya prevista en el Código de 1940.

No existiendo actas de las sesiones de la Comisión elaboradora del proyecto peruano, ni exposición de motivos, no sabemos qué razones pueden haber tenido sus miembros para proponer dicha modificatoria. Creemos, sin embargo, que es más conveniente para que la condena condicional cumpla con sus fines, que ella se extienda a las penas accesorias. Hacer efectiva estas penas podría significar poner obstáculos al proceso de autoeducación que debe propiciar la condena condicional. Además, es de recordar que el artículo 14 de la ley 9014 (art. 54 del Código penal) deja en poder del juez la decisión de extender o no su aplicación a las penas accesorias.

Se consideran penas accesorias de la pena de prisión, según nuestro Código penal, la multa (en caso de infracciones cometidas con fines de lucro o por codicia, art. 25), la privación de la patria potestad (siempre que el delito se haya cometido sobre los hijos del condenado o en perjuicio de los mismos, art. 33), la inhabilitiación especial (declarada en la sentencia, art. 35), la inhabilitación relativa (anexa a condena por infracciones cometidas con abuso del ejercicio de un mandato, cargo, etc., art. 36) y la confiscación (art. 46).

Si se tiene en cuenta, primordialmente, el fin de prevención individual de la condena condicional, hay que estimular y no entorpecer el proceso de autoeducación que ella comporta. Por esta razón, José Peco estima con justeza que: "Conceder condicionalmente la remisión y aplicar sanciones accesorias implicaría cohibir al delincuente y conspirar contra su rehabilitación. Lo lógico, lo natural, es conceder condicionalmente la remisión del cumplimiento de las sanciones accesorias con la principal. También es lógico y natural dejar subsistente la responsabilidad civil y las costas" (62).

Podemos pensar, sin embargo, que en la práctica cuando el juez prourcie una pena accesoria, lo hará estimando que es indigno de la condena condicional (63).

62. Proyecto de Código penal argentino, p. 187.

63. P. Logoz, Commentaires du Code pénal suisse, p. 180.

\section{Criterio admitido en la ley 9014}

El presupuesto de la condena condicional, referente a la pena, es de carácter formal; y es, generalmente, aceptado en la legislación extranjera. Esto es debido, justamente, al hecho de que la condena condicional fue, inicialmente, admitida como un eficaz medio de lucha contra los efectos nocivos de las penas privativas de corta duración.

Nuestro legislador al dictar la ley 9014 estableció otro criterio, dependiente más bien de la naturaleza de la infracción. Mediante el artículo 13 se modificó el artículo 53 del Código penal, en los siguientes términos: "El juez podrá a su juicio suspender la ejecución de la pena a los responsables de los delitos previstos en los artículos 82 y 83 del Código penal...". Ya no era, pues, la pena el primer criterio para discriminar los casos en que procede la condena condicional. De conformidad al artículo 83, el agente de la infracción no intencional ni culposa (no culpable), será también reprimible, en los casos de peligro social, cuando la ley lo prescriba expresamente, sustituyendo a la pena la medida de seguridad o educativa más adecuada determinada por la ley. Esto quiere decir, que ya no se trata de imponer una pena ("no hay pena sin culpabilidad"), sino de imponer al autor peligroso una medida de seguridad o educativa. Es, por tanto, inconcebible hablar en esios casos de condena condicional (64). Cómo pretender suspender, sin desnaturalizar completamente estas medidas, la ejecución del internamiento en un hospital o en un hospicio de delincuenies inimputables o semi responsables peligrosos (arts. 89 y 91), o de la colocación en una sección especial de una escuela de artes y oficios, o en una casa destinada exclusivamente a la educación por el trabajo, de delincuentes cuyos actos fueron consecuencia del desarreglo o de la ociosidad en que hubieran vivido. Además, no vemos cómo se cumpliria, precisamente a causa de la personalidad especial de tales agentes, la segunda condición establecida por la misma ley en el artículo 13: "si los antecedentes y el carácter del condenado...". Puede pensarse que me-

64. Es por esto que el Código penal italiano dispone que la suspensión condicional de la pena no puede ser concedida "allorche alla pena inflitta deve essere aggiunta una misura di sicurezza personale, perche il reo o persona che la legge presumesocialmente pericolosa" (art. 164, inc. 2, pf. $1^{\circ}$ ). Esta disposición es mantenida en el proyecto Gonella. 
diante la referencia al artículo 83 , el legislador no quiso referirse a las medidas de seguridad sino a las penas que con ellas se substituyen. Pero, en caso de inimputables no se aplica pena alguna; en relación con la medida para los delincuentes ebrios habituales, el artículo 41 dispone que se ejecutará después de cumplida la pena (no hay, pues, suspensión alguna); en réerencia a la medida destinada a los delincuentes semisalvajes (art. 45) no se suspende la pena sino se la reemplaza con tal medida. Quedarían los casos previstos en los artículos 42 y 91 del Código penal. Se trata de los delincuentes de imputabilidad relativa $y$ de los que viven en el desarreglo o la ociosidad. En el artículo 91, se establece que el juez "suspenderá la ejecución de la pena y ordenará" el internamiento; y en el artículo 42, se establece que el juez puede "suspender condicionalmente la ejecución de la pena y colocarle...". Si es a estos casos a los que quería referirse el legislador, no sólo se equivocó sino que reveló desconocimiento de lo que es la condena condicional.

El artículo 82, al cual también se refiere el artículo 13 de la ley 9014, trata de la negligencia o culpa. De esta manera, trató el legislador de restringir la aplicación de la condena condicional; pero al mismo tiempo ampliaba su concesión a casos en que la pena era superior a seis meses (65). En las decisiones publicadas por la Corte Suprema, no hemos podido encontrar casos en que esta disposición haya sido aplicada durante el tiempo en que estuvo en vigencia. Estimamos que dicha disposición ha sido tácitamente derogada por el artículo 286 del Código de procedimientos penales. Este artículo retorna, como lo hemos indicado antes, a la orientación del texto original del Código penal.

\section{5. c) Primera condena nacional o extranjera}

El texto original del artículo 53 del Código penal establecía, como requisito de naturaleza objetiva, que el delincuente "no hubiere sido objeto, por razón de delito intencional de ninguna condena anterior nacional o extranjera". La referencia al "delito intencio-

65. Generalmente, nuestro legislador ha previsto que la comisión culposa de ciertos delitos es sancionada con pena de prisión no mayor de dos años o con pena de multa. Por ejemplo: artículos 156 , párrafo $1^{\text {o }} ; 168 ; 262$, párrafo $1^{\circ} ; 263$, párrafo $3^{\circ} ; 267$, párrafo $3^{\circ} ; 274$, párrafo $2^{\circ}$. nal" parece provenir del proyecto suizo de 1918. Por el contrario, nuestro legislador se aleja del modelo helvético, el cual exigia que "el condenado no haya sufrido, en Suiza o en el extranjero, ninguna pena privativa de libertad...". Nuestro legislador prefirió, quizás siguiendo al Código penal argentino, otorgar la condena condicional sólo en los casos de "primera condena". El artícluo 286 del Código de procedimientos penales modifica este requisito en el sentido de que toda condena anterior nacional o extranjera dictada contra el delincuente impide que se le conceda la condena condicional (66).

La referencia que se hace a la condena extranjera es tan general que comprende hasta las impuestas por un acto que no sea considerado delito en nuestro país. La razón radica, quizás, en el hecho de que dichos antecedentes va impediría realizar un pronóstico favorable sobre la futura conducta del delincuente, puesto que revolaría en él una tendencia a realizar conductas prohibidas. En este punto, existe también una diferencia con las normas que rea!lan la reincldencia. El artículo 111 , párrafo 3 , establece "cuando se trate de condena extraniera, sólo se tomará ésta en cuenta bara los efectos de la reincidencia, si el hecho aue la hubiere motivado fuere también punible como delito en la Renúhlina”. Estimamos ove restrinair, mediante una exigencia parecida, la fórmula tan general de nuestra lev seria favorable para destacar aún más el aspecto preventivo de la condena condicional. En la leaislación extraniera reciente, podemos señalar aue la ley suiza de reforma nenal del 18 de marzo de 1971. incluye en el artículo 41 del Códian penal la siauiente disposición: "Las sentencias extranieras son tomadas en cuenta si no contradicen el orden público". Fórmula semeian+e es emnleada en la misma ley en relación con la reincidencia (art. 67, No 2).

Quien sea merecedor de una pena mavor de seis meses de orisión $v$ que hava sido, anteriormente, condenado en razón de un delito o falta a una pena de musta o de inhabilitación temporal, etc. (no es necesario que la hava cumplido en todo o en parte), no podrá ser sometido a la condena condicional. Dicha condena anterior puede haber sido dictada en cualquier época. En esto también, el legislador nacional abandona

66. En el proyecto de 1972, se vuelve a exigir que la condena anterior debe ser dictada a la ocasión de la comisión de un delito doloso (art. 53, pf. $1^{9}$ ). 
el modelo suizo que fijaba un plazo de diez años. Este plazo fue disminuido, posteriormente, a cinco años, que es el mismo fijado en la norma que regula la reincidencia. Asimismo, la legislación suiza exige en ambas instituciones que el delincuente haya sufrido pena privativa de libertad.

En nuestro Código penal, por el contrario, no existe tal concordancia. Así el artículo 111 requiere para la reincidencia que el condenado haya cumplido, anteriormente, en todo o en parie una pena privativa de libertad; el artículo 286 del Código de procedimientos penales, como lo hacía el artículo 53 del Código penal, considera suficiente para no otorgar la condena condicional que al delincuente ya se le haya impuesto una condena. El caso peruano es, para nuestro conocimiento, excepcional. Los legisladores siempre han regulado uniformemente ambas instituciones, ya sea exigiendo la ejecución parcial o total de la condena anterior (Suiza, Alemania, Italia, Bélgica) o estimando sufic:ente la imposición de una condena (Francia, Argentina).

En doctrina se ha discutido, con frecuencia, si la condena impuesta al delinclente por un acto cometido posteriormente al acto que actualmente se juzga, puede ya enervar la posibilidad de conceder la condena condicional (67). En 1930 un Tribunal Correccional de la República se pronunció negativamente. Consideró que no es aplicable el artículo 53 , inciso $1^{\circ}$, del Código penal "porque el encausado no ha infringido la ley, después de haber sufrido la condena condicional... y de haberse tenido constancia en autos de la existencia de estos actuados, se hubieran acumulado ambos procesos, pronunciándose un solo fallo, y la situación procesal que se presenta no puede apreciarse desfavorablemente para el encausado, negándosele el beneficio de la condena condicional, no procediendo por lo mismo, hacer efectiva la pena, que fue suspendida en la anterior condena...". La Corte Suprema declaró haber nulidad en esta sentencia recurrida, apoyándose en el Dictamen del Fiscal. Este afirmó que "si consta de autos que ya el agente ha sufrido una condena anterior, en el momento en que es sentenciado por nuevo delito, poco importa que su segunda delincuencia se hubiese realizado antes de ser condenado, ya que para los efectos de la ley basta que esa conde-

67. Ver Ricardo Núne\%, Derecho penal argentino, ' $\mathrm{T}$ '. II, p. 526-527. na haya existido en el momento en que se impone la nueva" (68).

Del texto de la ley se desprende, a diferencia de lo que slicede en la reincidencia, que la concesión de la condena condicional no se funda en el fracaso de una medida judicial (pena). Todo gira en torno al hecho de que el candidato a la condena condicional no haya sido objeto de una condena anterior.

Cabria aún preguntarse, si es posible conceder la condena condicional cuando la condena anterior fue impuesta condicionalmente. La respuesta supone la determinación de los efectos de la condena condicional (69). Aquí, nos basta decir que si la nueva infracción se comete dentro del plazo de prueba será de aplicación el artículo 56, inciso 19 , in fine. Por el contrario, si esta infracción es cometida una vez transcurrido dicho plazo, seria posible conceder nuevamente la condena condicional, por cuanto el artículo 55 establece que el "juzgamiento se considerará como no producido", es decir que la condena desaparece (70).

\section{Amnistía e indulto}

Procede conceder, igualmente, la condena condicional al delincuente amnistiado o indultado, por cuanto la amnistía "suprime legalmente el hecho punible a que se refiere e implica el perpetuo silencio respecto de él. El indulto suprime la represión del hecho punible (art. 126). En la misma condición se encontrará el rehabilitado, ya que el artículo 131 establece que "el juez ordenará la supresión (de la condena del Registro judicial), quedando así la historia del condenado libre de todo antecedente penal".

En fin, lo que interesa es que el candidato a la condena condicionel no tenga en su haber, en el momento de ser juzgado, una condena anterior cuya inscripción en el Registro judicial no haya sido borrada.

La condena extranjera debe ser conocida por la vía legal (71).

No se trata, pues, del primer delito o falta. Ya hemos visto que es posible conceder la condena condi-

68. Ejecutoria del 21 de mayo de 1932, in Revista de los Tribunales 1932, p. 109.

69. Ver infra No 28.

70. Ver infra Nos. 25 y 28

71. Manuel G. Abastos, Revista de Derecho y Ciencias Políticas, Lima 1938, p. 313. 
cional cuando la pena (no mayor de seis meses de prisión o multa) es impuesta en consideración a un concurso real de delitos (72).

\section{Delincuentes primarios y ocasionales}

Si se considera delincuente primario al que no ha sufrido en el Perú ni en el extranjero ninguna condena $y$ al que condenado condicionalmente no dio lugar a la revccación, al rehabilitado, al amnistiado, bien podemos decir que la condena condicional está destinada a los delincuentes primarios (73).

Por el contrario, si tenemos en cuenta la tercera condición establecida para conceder la condena condicional (pronóstico de que el condenado no cometerá nuevo delito), se puede estimar que no es suficiente el carácter primario del delincuente, sino que éste debe ser además un ocasional, entendiéndose por tal "el sujeto $\sin$ antecedentes penales, dotado de sensibilidad moral, que habiendo delinquido una vez, no ofrece la probabilidad de cometer nuevo delito" (74). En las ejecutorias de la Corte Suprema se habla, generalmente, de delincuente primario (75).

\section{8. d) Pronóstico favorable sobre el futuro comportamiento del condenado}

El artículo 286 del Código de procedimientos penales establece, siguiendo en parte el artículo 53 del Código penal, como última condición "que los antecedentes y el carácter del condenado hagan prever que no cometerá nuevo delito" (76).

De esta manera, se exige al juez el análisis detenido del caso individual. Para poder conceder la condena condicional, él debe, después de observar los antecedentes y el carácter del delincuente, concluir formulando un pronóstico favorable sobre su futuro com-

72. Ver supra Nos. 7 a 11 .

73. Ver Luis Bramont Arias, Código penal anotado, Lima 1966, p. 125.

74. Manuel G. Abastos, Revista de Derecho y Ciencias Políticas. p. 306. Respecto a que se trata del primer delito, ver supra $\mathrm{N}^{\text {? }}$

75. Ver: Ejccutoria del 19 de diciembre de 1941, in Revista de los Tribunales 1942, p. 25, y del 23 de abril de 1953, in Revista de Jurisprudencia Peruana 1953, p. 989.

76. Artículo 53, inciso 2": "Si los antecedentes y el carácter del condenado hacen prever que esta medida le impedirá cometer nuevo delito". portamiento. La sola esperanza de que no volverá a reincidir no es suficiente. En caso de duda no puede admitirse la aplicación del principio "indubio pro reo" (77).

No se puede admitir, por la necesidad que hay de examinar al delincuente, la concesión de la condena condicional en procesos contra ausentes. La Corte Suprema lo declara, expresamente, en una de sus ejecutorias (78).

Este pronóstico exige una apreciación individual de todas las circunstancias que permitan prever la futura conducta del autor. Los írdices objetivos y subjetivos de peligrosidad enumerados por nuestro legislador en el artículo 51 del Código penal, pueden servir de guia al juez en esta tarea. Indicios que conducen, justamente, al conocimiento de la personalidad del delincuente.

Esto supone, de la parte del juez, un esfuerzo mayor que el de la simple constatación, mediante el boletín de condenas, de que el inculpado tiene o no antecedentes judiciales o penales. Esta insuficiente manera de formular el pronóstico de no reincidencia prima en nuestro medio. La causa principal de esta situación es la defectuosa organización de la administración judicial. La acumulación de procesos en los tribunales y juzgados impide el estudio serio de la personalidad de cada inculpado.

Esta exigencia basada en los antecedentes y el carácter del condenado, fundamento para considerar esta institución como medio de individualización de la represión penal, excluye la posibilidad de que el juez niegue la condena condicional en razón de criterios formales generales; por ejemplo, la necesidad de reprimir severamente a los autores de ciertos delitos, como aquéllos contra el honor sexual o contra los deberes de función.

La Corte Suprema en varias de sus decisiones se aleja, sin embargo, de esie criterio. En 1935, por ejemplo, la Segunda Sala de la Corte Suprema, al conocer que la Corte Superior de Arequipa otorgaba con cierta frecuencia la condena condicional (casos de delitos contra el honor y el patrimonio), acordó recomendar a dicha Corte "proceda a la debida aplicación del Título VI del Código perial sujetándose en todo lo que

77. Lackner y Massen, Strafgesetzbuch, p. 52.

78. Ver: Boletín de la Corte Suprema, año 1 , No $1, p$. 45. 
a dicha condena se refiere a las prescripciones en él establecidas, todo lo cual contribuirá seguramente a hacer más respetables y efectivas, las sanciones autorizadas por la ley penal, en relación con la comisión de los diversos delitos cuya frecuencia transforma la vida jurídica y normal de la sociedad'. Esta última frase supone erigir en obstáculo el efecto de intimidación general atribuído a la pena, descuidando el factor individual a que se refiere el legislador. Esa misma opinión, defendida por el Fiscal en su dictamen, sirve de base a la Corte Suprema para negar la condena condicional al autor del delito de abigeato. Sostenía el Fiscal que "'el abigeato es un delito que se está repitierido con mucha frecuencia; debe ser reprimido en forma seria..." y "que una prisión suspendida resulta hasta cierto punto irrisoria" (79). Lo mismo sucede con los delitos contra la vida, el cuerpo y la salid cometidos culposamente (80).

Este criterio se refleja, igualmente, en la política legislativa del Estado, quien descarta, expresamente, la concesión de la condena condicional en ciertas clases de delitos. En el caso, por ejemplo, de la ley 10202 del 22 de julio de 1945 que reprime el delito de abigeato (art. 10); del Decreto Ley No 17716 del 24 de junio de 1969 (Ley de Reforma Agraria), en cuanto reprime ciertas formas de los delitos de usurpación y contra la tranquilidad pública (Tercera disposición especial); del Decreto Ley No 17816 del 16 de setiembre de 1969 que prohíbe la caza de la vicuña (art. 10); del Decreto Ley No 19049 del 30 de noviembre de 1971, que reprime ciertas formas de terrorismo.

No creemos que la exclusión total de la condena condicional en relación con determinados delitos sea la solución adecuada para luchar eficazmente contra tal tipo de delincuencia. La restricción del campo de aplicación de la condena condicional, significa en esos casos la manifestación de una política puramenie represiva, la cual olvida la naturaleza y fines de la institución que estudiamos. Por tratarse, justamente, de una medida cuya aplicación depende, sobre todo, de la personalidad del agente, consideramos que es más oportuno dejar en manos del juez (estableciéndolo en forma expresa) la facultad de no otorgar la condena condicional, si por razones de prevención gene-

79. Ejecutoria del 26 de octubre de 1942, in Anales Judiciales 1942, p. 327.

80. Ejecutoria del 23 de octubre de 1952, in Revista de Jurisprudencia Peruana 1952, p. 2983. ral se considera necesaria la ejecución de la pena, a pesar de que se den todos los requisitos de la condena condicional. Este es el criterio admitido, por ejemplo, por los legisladores germano y sueco. El artículo 23 , No 3, del Código penal alemán estatuye que la cordena cordicional no se concederá, en caso de penas privativas de libertad cuya duración no sea inferior a seis meses, si la defensa del orden público lo exige (81). El Código penal sueco contiene una disposición más general, por cuanto no establece límite respecto a la duración de la pena (82).

\section{Arbitrio judicial en la concesión de la condena condicional}

Dadas las tres condiciones exigidas, el juez debe, por regla general, conceder la condena condicional. Pero, él no está obligado a hacerlo. Sin embargo, la ley al establecer que el juez "podrá suspender la ejecución de la pena" no le está concediendo un poder discrecional de decisión. Con esta expresión, el legislador ha admitido la posibilidad de que el juez niegue la condena condicional en razón de una circunstancia que no esté indicada expresamente en la ley. Esto no significa que se deje al juez plena libertad para decidir. No puede, sin violar el sentido de la ley, considerar otras condiciones generales como las que hemos señalado al final del acápite precedente. Sólo circunstancias propias al caso que se juzga, más exactamente, a la personalidad del delincuente, justifican tal negativa a pesar de que se den las tres condiciones nombradas por la ley (83). En buena cuenta, el criterio deLerminante que ha de tener en cuenta el juez es la finalidad de la condena condicional: evitar que un delincuente no peligroso reincida, alejándolo de la prisión y dándole ocasión para que se autoeduque.

\section{0. e) Periodo de prueba: reglas de buena conducta}

El artículo 53 del Código penal, en su penúltimo párrafo (ab initio), establecía que "la sentencia mencio-

81. Dice textualmente esta disposición: "Bei der Verurteilung zu Freiheitsstrade von mindestens sechs Monaten wird die Vollstreckung nicht ausgesetzt, wenn die Verteidigung der Rechtsordnung sie gebietet", Bundesgesetzblatt, No 88, 1969.

82. Capítulo XXVII, artículo $1^{\circ}$.

83. Paúl Logoz, Commentaires du Code pénal suisse, p. 183; Vital Schwander, Das schwizerische Strafgesetzbuch unter besonderer Berücksichtigung der bundesgerichtlichen Praxis, 2 $2^{\text {a }}$ edición, Zürich 1966, p. 184. 
nará las razones que justifiquen la concesión de la condena condicional..." (84). El Código de procedimientos penales y la ley 9014 no dicen nada al respecto y tampoco contienen normas que to contradigan. Estimamos, pues, que el juez debe establecer en la sentencia el por qué se otorga la condena condicional. Debiendo indicar de manera concreta las circunstancias que le han permitido elaborar el pronóstico favorable sobre la futura conducta del condenado. Esta disposición tiene como fin, exigir de la parte del juez, un cuidado especial para conceder la condena condicional. Además, sirve de garantía para el propio condenado (85). Por estas mismas razones, el mismo párrafo 53 obligaba al juez a fijar, en la sentencia, las reglas de conducta que debia respetar el condenado condicionalmente. A título de ejemplo, dicha disposición mencionaba la obligación de aprender un oficio, de residir en un lugar determinado, de abstenerse de bebidas alcohólicas, o de reparar el daño en un término dado.

El artículo 15 de la ley 9014 modificó esta disposición en los términos siguientes: "El Tribunal Correccional al conceder la suspensión de la pena, fijará las reglas de conducta a que quedará sometido el sentenciado y la forma de hacer efectiva la responsabilidad civil". Los ejemplos dados originalmente por el legislador son útiles para interpretar esta norma.

En la práctica, los jueces se limitan a establecer reglas de carácter general que debe observar el condenado condicionalmente. Por ejemplo, en caso de delitos de seducción: "observar buena conducta", "no tener trato sext:al con menores", "no frecuentar cantinas ni lugares inmorales", "evitar malas compañias"; en caso de lesiores culposas: "manejar (vehículos) con prudencia", "observar fielmente las disposiciones del Reglamento de tránsito". En nuestra opinión, el juez debería abandonar estas tradicionales y estereotipadas frases, y tratar de establecer exigencias concretas que impuisen al condenado a bien comportarse y que por su misma raturaleza sean fáciles de controlar.

84. El Anteproyecto de Código penal suizo, texto agosto de 1915 , estatuía en su artículo 41 , párrafo 2 : “Le jugement mentionnera les raisons qui justifient l'octroi du sursis, les motifs qui ont engagé le juge a dispenser exceptionnellement le condamné du patronnage et les regleas de conduites imposées par le juge".

85. E. Zürcher, Exposé de motifs, p. 109.

\section{Duración del período de prueba}

Al tratar de la naturaleza juridica de esta institución (86), ya tuvimos oportunidad de señalar que la condena condicional no es una gracia, un beneficio otorgado sin más al inculpado. Además de ser necesario que, al momento de ser juzgado, el delincuente merezca ser sometido a la condena condicional, es indispensable que con su comportamiento posterior al juzgamiento no la desmerezca. El artículo 55 estatuye que el período de prueba durará cinco años. Durante los cuales el condenado no debe ser "objeto de ninguna condenación" y no haber "infringido las reglas de conducta impuestas por el juez". Este período de prueba es de sólo un año cuando la condena condicional ha sido impuesta con ocasión de sancionar al autor de una falta (art. 383, inc. 4\%).

La misma rigidez en la determinación de la duración del plazo de prueba subsiste en el artículo 16 de la ley 9014.

En las disposiciones respectivas de los proyectos suizos se fijó, por el contrario, un mínimo y un máximum (anteproyecto 1915 y proyecto 1918, dos a cinco años), dentro de los cuales el juez escogerá el lapso propio a cada caso particular. Nuestro legislador parece haber seguido el Código penal argentino, cuyo texto original establecía un período igual al de la prescripción de la pena (art. 26). El artículo 123, inciso 6 , de nuestro Código penal señala, justamente, que el derecho a ejecutar la pena de prisión no mayor de un año y las otras penas (multa, inhabilitación, etc.) se extinguen a los cinco años. Esta misma relación se presenta entre el plazo de prueba de la condena condicional en caso de falta y el lapso que debe transcurrir para que prescriba la pena en relación al mismo tipo de infracciones (art. 383, inc. $7^{\circ}$ ).

La duración del periodo de prueba había sido, igualmente, establecida en armonía con el lapso que debia transcurrir para que el condenado a pena de prisión solicite su rehabilitación, después de cumplida o prescrita la pena (art. 131 del Código penal, pf. 2?). Este período ha sido reduc:do a tres años mediante el artículo 339 del Código de procedimientos penales, sin terierse en cuenta la situación de los condenados condicionalmente.

86. Ver supra $\mathrm{N}^{0} 3$. 
En la legislación extranjera predomina el criterio de dejar c'erta libertad al juez para la fijación del plazo de prueba en cada caso particular (87).

\section{Revocación en caso de violación de las reglas de buena conducta}

Durante el periodo de prueba el condenado debe comportarse bien; pero no es necesario que tenga una conducta intachable. La ley exige únicamente que cumpla con las reglas de conducta que le ha impuesto el juez y no cometa un nuevo delito intencional (art. 56 del Código penal y art. 16 de la ley 9014). Si el condenado no satisface estas exigencias se le revoca la condena condicional.

El simple incumplimiento de las reglas de conducta no basta para la revocación. Lo contrario parece deducirse del artículo 55 del Código penal que estatuye sobre los efectos de la condena condicional y que se refiere tan sólo a "sin haber infringido las reglas de conducta". Es necesario que el condenado las infrinja y que, a pesar de la advertencia de la autoridad, persista en hacerlo. Esto se deduce del segundo párrafo del artículo 56 del Código penal y está, expresamente, fijado por el artículo 16 de la ley 9014 (88).

La autoridad a que se hace referencia es la policía, que, como muy bien dice el profesor Abastos, es la menos indicada para tales menesteres (89). Nuestro legislador no ha previsto, expresamente, una organi-

87. Señalan un plazo mínimo de un año y máximo de cinco años, la ley belga de 1964 y el proyecto austriaco (art. 3, pf. $4^{\circ}$ y art. 45 , pf. 1 , respectivamente), aumentan a ese a dos años, conservando el mismo máximo, el Código penal alemán y el Código penal suizo (art. 24 y 41, respectivamente); el Código penal sueco se limita a fijar un plazo de dos años (Capítulo XXVII, art. 3, pf. 1). El Código de procedimientos penales francés, como nuestra legislación, señala un plazo de cinco años (art. 735 ).

88. El mismo legislador decía, muy ligeramente, en su exposición de motivos que "El juzgamiento se considera como no producido, si transcurren cinco años sin que el condenado haya sido objeto de ninguna otra condenación por delito intencional y sin haber infringido las reglas de conducta", Código penal, edición oficial, p. 169. La comisión revisora del Código no ha corregido este defecto de técnica legislativa en su proyecto de 1972.

89. Revista de Derecho y Ciencias Políticas, 1938, p. 315. zación ad-hoc para controlar a los condenados condicionalmente. Sin embargo, cabria preguntarse si hubiera sido posible recurrir a los Consejos locales de patronato, los cuales, según el artículo 406 , inciso 2 , cumplirán la función de vigilar "por medio de los empleados de la Inspección general de prisiones, de los inspectores que designare con ese fin y de los delegados de las sociedades particulares de patronato, a los liberados provisionales o definitivos"; a quienes protegerá procurándoles trabajo y velando de todos modos por su readaptación a la vida social". Creemos que esta disposición hubiera podido ser utilizada, por jueces y autoridades administrativas advertidos, para implementar el control que requiere la condena condicional para su eficaz funcionamiento.

\section{Condena condicional y "Probation"}

La sumisión del liberado condicionalmente a un control calificado, eficaz y discreto es el complemento necesario de la condena condicional. Este es el elemento que asegura el notable éxito del sistema inglés. Si se tiene en cuenta que casi siempre la debilidad o la falta de protección, moral y material, son las causas por la que el condenado haya incursionado en la delincuencia; la asistencia, el consejo y el control son, también, por eso, casi siempre indispensables. No basta, pues, conceder al delincuente primario una oportunidad para autoeducarse; es imperioso, por el contrario, prestarle la ayuda necesaria para que logre éxito en la prueba.

Se ha comprobado en Derecho comparado que en los paises donde prima el simple régimen de la condena condicional (sin sumisión al patronato), tal era el caso especialmente en Francia, no fueron alcanzados los resultados tan esperados. A pesar de la ausencia casi total de esiadísticas en nuestro medio, podemos afirmar, teniendo en consideración como la condena condicional es aplicada, que la situación es la misma. Esta realidad ha impulsado a la mayoría de paises a incorporar determinadas medidas de control y asistencia como complemento de la institución que estudiamos; lendencia que se ha acentuado con la adopción en las legislaciones de la institución de la "probation".

Ejemplo de esta evolución es la legislación belga, la primera en introducir la remisión de la ejecución de la pena en el continente europeo. En 1888, se admite esta institución para los delincuentes primarios (sin establecer medidas de control) condenados a pe- 
na no mayor de seis meses; en 1947, se extiende su aplicación a todos los casos en que la pena impuesta no es mayor de dos años, y se establece que su revocación procederá sólo en caso de reincidencia y cuando la pena impuesta sea al menos de un mes de duración; en 1964, se amplía su aplicación a toda pena no mayor de tres años; se estatuye que la revocación sólo procederá en caso de pena mayor de dos meses; se incorpora la suspensión del pronunciamiento de la condenación y establece la aplicación de la "probation" en caso imponerse la remisión de la ejecución de la pena y de la suspensión de la condenación. Casi idéntico sistema ha adoptado el legislador francés en los artículos 737 y 738 del Código de procedimientos penales. En Holanda y Noruega se iniciaron, hace ya algún tiempo, reformas legislativas parecidas (90). En Suiza, siempre se ha previsto la sumisión del liberado al control del patronato (91). En Alemania, el nuevo Código penal estatuye en su artículo 24c que el juez someterá al condenado a la vigilancia y dirección de un "Bewährungshelfer", si es lo indicado para evitar que vuelva a delinquir. El contra proyecto alemán de 1966, elaborado por un grupo de profesores, establecía también la colocación del condenado bajo el control de un tutor (art. 40); pero iba más lejos al estatuir que "el Tribunal puede recomendar a las autoridades, particularmente, a aquéllas que son competentes en materia de trabajo, de vivienda, de asistencia social y de salud públi$\mathrm{ca}$, de tomar las medidas necesarias que exija la reinserción del condenado en la comunidad juridica". De esta manera se pretendía incorporar en la ley positiva el principio moral de la corresponsabilidad de la sociedad y trataba, al mismo tiempo, de eliminar las causas de la criminalidad, en relación al caso particular, que provienen del medio ambiente (92).

\section{Reparación civil}

Debido, pues, a la falta de un sistema de control sobre el comportamiento del condenado condicionalmente durante el periodo de prueba, es que sólo con ocasión de un incidente se establecerá; en la prácti-

9). Ver Ancel-Strahal, Le droit pénal des pays scandinaves, p. 137 y s.

91. Ver proyecto de 1918, art. 39, anteproyecto de agosto 1915, art. 41.

92. Peter Noll, Revue de Droit pénal et de Criminologie 1969, p. 759 . ca, la inobservancia, por parte del condenado, de una regla de conducta; $y$, en definitiva, sólo es controlable el cumplimiento del pago de la reparación civil (93).

Nuestros jueces y tribunales no llevan la cuenta de las revocatorias de las condenas condicionales por ellos impuestas. De las investigaciones que hemos realizado, hemos podido constatar que, generalmente, sólo el cumplimiento en el pago de la reparación civil puede ser controlado. Muy raro es el caso en que se revoque por incumplimiento de cualquier otra regla de conducta.

En diversas oportunidades la Corte Suprema se ha visto obligada a declarar que el no cumplir con hacer efectiva la reparación civil (en casos de delitos contra l:bertad y el honor sexual, también, la dote), es causa de revocatoria de la condena condicional (94). Estos pronunciamientos de la Suprema se han debido a que los tribunales o jueces no habian fijado el "término" a que hace referencia el artículo 53 ó a "la forma" de hacerla efectiva, indicada por el artículo 15 de la ley 9014. El juez debe, en la sentencia, fijar como regla de conducta el pago de la reparación civil en un plazo determinado, el cual no puede ser mayor de cinco años (duración del período de prueba).

\section{Revocación en caso de comisión de un nuevo delito}

La revocatoria de la condena condicional procede, igualmente, cuando el condenado comete nuevo delito intencional. Esto lo establece, claramente, el artículo 16 de la ley 9014. Por el contrario, el artículo 55 del Código penal, se refería a que el condenado no haya "sido objeto de ninguna otra condenación". De acuerdo con esta norma, no interesaba que tipo de infracción daba lugar a la nueva condenación; era suficiente, por ejemplo, un delito culposo o una falta. La doctrina interpretaba restrictivamente esta disposición, relacionándola con el artículo 56, primer

93. Artículo 66: "La reparación civil comprende: $1^{\text {" }}$ La restitución de la cosa; $2^{\circ}$ La reparación del daño causado; $3^{\circ}$ La indemnización del perjuicio material o moral irrogado a la víctima del delito, a su familia, o a un tercero".

94. Ejecutoria del 11 de diciembre de 1957, in Anales Judiciales 1957, p. 96. 
párrafo (95). El legislador sostuvo en su exposición de motivos (96) el mismo criterio, sin percatarse quizás de que el texto de los artículos 55 y 56 podian ser diferentemente interpretados.

De acuerdo al texto del artículo 16 de la ley 9014 este problema de interpretación desaparece: la revocatoria procede sólo cuando se somete, durante el periodo de prueba, un delito intencional. Las infracciones culposas y las faltas sólo darian lugar a la revocatoria cuando constituyen una infracción reiterada de las reglas de conducta fijadas por el juez.

En la legislación extranjera se tiende a atenuar la severidad de las reglas que fijan los casos en que procede la revocación de la condena condicional. La ley belga de 1964 ordena que se producirá de pleno derecho sólo cuando el autor por el delito cometido durante el período de prueba, merece pena efectiva mayor de seis meses; en caso de pena mayor de un mes pero menor de seis meses, establece que la revocación será facultativa. De no ordenar la revocación, el juez puede - siempre de acuerdo a la ley belga- reemplazar la "remisión condicional simple" de la pena por la "remisión condicional con probation" o establecer nuevas condiciones (97).

\section{Efectos de la revocación}

El condenado condicionalmente que cometiera, dentro del período de prueba, un nuevo delito intencional, sufrirá la pena impuesta en la primera condenación y la que le corresponde por el segundo delito conforme a lo dispuesto en las leyes de la reincidencia (art. 56).

La exigencia de que el nuevo delito sea intencional está en armonia con el párrafo cuarto del artículo 111, que dice: "No se computarán (para la reincidencia) las condenas por faltas, ni por delitos culposos, ni por los exclusivamente militares, ni por los politico-sociales no cometidos con homicidio, incendio o saqueo". Cuando se trate de faltas, se considerará qu'e sus autores son castigados por el solo hecho de cometerlas (consumación), sin tener en cuenta si hubo intención o negligencia (art. 383, inc. 19).

95. Luis Bramont Arias, Código penal anotado, p. 128. 96. Código penal, edición oficial, p. 168.

97. Artículo 13; ver: Revue de Droit pénal et criminologie 1967 , p. 759 .
Mediante el artículo 56 del Código penal, el legislador no buscó, originalmente, señalar las condiciones de revocación, sino solucionar de manera directa el problema de saber si el condenado condicionalmente que volviera a delinquir debia ser considerado como reincidente. Esto era necesario debido a que, según el criterio admitido en el artículo 111, sólo es reincidente el que después de haber sufrido en todo o en parte una condena a pena privativa de libertad, impuesta en sentencia nacional o extranjera, incurre, antes de pasar cinco años, en otro delito reprimido también con pena privativa de libertad.

En la legislación extranjera se admite, como agravarte de la pena, a veces la reincidencia "ficticia" (impropia) y otras veces la "verdadera" (propia). Esta última es considerada en Alemania, Suiza, Perú, Panamá, Paraguay, etc. La reincidencia ficta es prevista en Francia, España, Argentina, Brasil, Uruguay, etc. (98).

En Italia, donde Carrara sostuvo el criterio de la reincidencia "verdadera", se ha admitido en el Código penal tanto la reincidencia ficta como la verdadera. En el primer párrafo del artículo 99, se estatuye: "Chi dopo essere stato condannato per un reato, ne commette un altro, soggiace a un aumento fino a un sesto della pena da infliggere per il nuovo reato"; en el párrafo segundo, dispone que "La pena è aumentata fino alla meta: 3 ? - se il nuovo reato è stato commesso durante o dopo l'esecuzione della pena, ovvero durante il tempo in cui il condannato si osttrae volontariamente all'esecuzione della pena'. Al respecto, Rocco manifestaba en la exposición de motivos de su proyecto, que "In tal guisa, le distinzioni scolastiche tra recidiva propia e finta, generica e specifica, sono state vivificate, dando loro un contenuto reale, inspirato al criterio direttivo di tutto el Progetto, cioè di considerare in particolar modo la personalita del delinquente"' (99).

Nuestro legislador establece, en relación con el coridenado condicionalmente que comete nuevo delito intencional durante el período de prueba, la reincidencia "impropia" (ficticia), porque para él, pre-

98. Respecto a América Latina, ver: Jiménez de Asúa, Códigos Penales Iberoamericanos - Estudio de legislación comparada, Caracas 1946, p. 360 y s.

99. Lavori preparatori del Codice Penale e del Codice di procedura penale, volume V, parte 1\%, Roma 1929, p. 149. 
cisamente, la condena condicional no es sólo la suspensión de la ejecución de la pena. Este criterio no ha sido, por el contrario, admitido en el Código de Justicia Militar de 1963, que en su artículo 68, párrafo segundo, estatuye: "Si cometiere nuevo delito intencional (dentro del periodo de prueba), sufrirá la pena impuesta en la primera condena y la que le corresponda por el segundo delito".

El que la reincidencia sea ficta (impropia) no significa que dejará de agravarse la pena de acuerdo al artículo 112 del Código penal, si es que además se cumplen las otras condiciones legales. Se puede, de "lege ferenda", ser contrario a la severidad conque en nuestro Código se admite la reincidencia ficta para los condenados condicionalmente. Sin embargo, de "lege lata", es correcto el cambio de criterio habido en la jurisprudencia de la Corte Suprema, quien declara ahora reprimible, de acuerdo a las reglas de la reincidencia, al liberado condicionalmente que vuelve a delinquir dentro del período de prueba (100).

100. Hasta hace poco tiempo nuestro máximo Tribunal sostuvo que "exigiendo el artículo 111 del Código penal, que la pena se haya sufrido en todo o en parte, no es reincidente, quien, condenado a prisión condicional comete nuevo delito intencional antes de vencerse cinco años de la condena anterior. Conforme a lo dispuesto en el artículo $56 \mathrm{del}$ acotado, el reo debe cumplir la pena impuesta en la primera sentencia, además de la que le corresponde por el nuevo delito" (Ejecutoria del 4 de diciembre de 1947, in Anales Judiciales 1947, p. 327; cf. ejecutorias del 22 de marzo de 1960 , in Anales Judiciales 1960, p. 129; del 29 de abril de 1952, in Revista de Jurisprudencia Peruana 1952, p. 2325; del 31 de mayo de 1961, in Anales Judiciales 1961, p. 114). Actualmente, la Corte Suprema admite que "esta norma (art. 56) no es implicante con la contenida en el artículo 111 del mismo código que exige como requisito para la reincidencia que se haya cumplido en todo o en parte una condena privativa de libertad, porque la condena condicional, por las razones en que se sustenta y por su propia naturaleza, fija el período de prueba, durante el cual, cuando menos, el beneficiado se verá impedido de cometer nuevo delito; que fracasada la previsión del juzgador, de otro lado, hace obligatoria la ejecución de la pena, y, por tanto, el que vuelve a delinquir asume la categoría de reincidente, pues el beneficio indicado no ampara el rigor de la ley -art. 111 - sino que suspende la ejecución de la pena en aras de una política criminal..." (Ejecutoria del 5 de noviembre de 1971, in Anales Judiciales 1971, p. cf. ejecutoria del 27 de junio de 1970, in Revista de Juris-

\section{Concurso real retrospectivo}

El artículo 56, ab initio, trata del denominado "concurso real retrospectivo". Establece que si después de condenar condicionalmente a un infractor, se descubre que cometió, antes de dicha condena y dentro del plazo de prueba, otro acto delictuoso, se revocará la condena condicional y se hará efectiva la pena impuesta. Esta disposición nada dice respecto a la nueva pena que debe imponerse por la infracción descubierta. Consideramos que es de aplicación el artículo 110 que, en relación a sentencias definitivas, estatuye: "se le someterá (al mismo condenado) a un nuevo juicio y se le aumentará la pena o se le aplicará la nueva pena correspondiente". No se le podrá considerar, por to tanto, como reincidente.

Si sólo se llegan a conocer los antecedentes delictivos una vez transcurridos los cinco años del plazo de prueba, la pena impuesta condicionalmente no se hará efectiva.

La pena fijada de manera condicional no puede prescribir ya que es inejecutable. La prescripción sólo puede transcurrir a partir de que la condicionalidad es revocada (101).

\section{Buen comportamiento durante el periodo de prueba}

Si ninguna de las causas de revocación se presentan durante el período de prueba, "el juzgamiento

prudencia Peruana 1970, p. 1488: del 20 de febrero de 1973. inédita. recaída en el expediente $N^{0}$ 2193-72, procedente del Callao. En este último caso, el Señor Vocal Barrós Conti sostuvo en un interesante voto singular que "no quiere esta circunstancia (art. 56, in fine)" significar que resultan de aplicación los artículos $111 \mathrm{y}$ 112 del Código penal, pues, de haber sido así, la redacción hubiera sido distinta y al referirse aquel artículo 56 .... “a lo dispuesto por las leyes de la reincidencia” no hace otra cosa que aludir a la reincidencia "ficticia", desde que el mismo artículo señala expresamente, a más de la pena impuesta en la primera condenación, se le impondrá "la que le corresponde por el segundo delito", mas no la pena tasada que se impone en el caso de la reincidencia "verdadera", todo lo que viene claramente a significar que esa disposición del Código está amparada en el concepto doctrinario de la reincidencia "ficticia".

101. Paul Logoz, Commentaires du Code pénal suisse p. 187 . 
se considerará como no producido". Es decir, no sólo la pena dejará de ser ejecutada, sino que se considera, mediante una ficción, que el juzgamiento no ha tenido lugar. No se trata de una simple condición suspensiva, de la cual se hace depender la ejecución de la pena impuesta. Se trata más bien de una condición resolutoria que cumplida hace desaparecer, pura y simplemente, todo antecedente penal. Es de admitir por esto, que el buen comportamiento del cordenado condicionalmente, durante todo el período de prueba, comporta su rehabilitación automática (E) interesado podrá obtener un certificado en que figure $\sin$ antecedentes penales) (102).

Nuestro legislador emplea, siguiendo el texto del inciso 4 9 del artículo 39 del proyecto suizo de 1918, el poco castizo término de "juzgamiento", en lugar de "condenación" que es el equivalente de la palabra francesa "condenation" utilizada por el legislador helvético. A la condenación se refiere, por ejemplo, el legislador argentino.

Lo que se debe comprender por "juzgamiento" debe ser la condenación, y no su significado procesal de juicio oral, segunda etapa del proceso penal (103). En este sentido, lo ha empleado también el legislador en los artículos 118, inciso 3ํ, párrafo $2^{\circ}$ y 121 del Código penal.

\section{Conclusión}

La condena condicional es uno de los medios más eficaces substitutos de las penas privativas de libertad de corta duración. Sin embargo, el máximo aprovechamiento de esta institución, de múltiples fines, no se logra mediante la simple suspensión de la eje-

102. Sobre las relaciones con la rehabilitación de condenados a penas efectivas, ver supra $\mathrm{N}^{2} 2 \mathrm{I}$.

103. Artículo $1^{\circ}$ del Código de procedimientos penales. El artículo 9 del mismo Código expresa: "Corresponde a la Justicia penal ordinaria la instrucción y el juzgamiento de los delitos y las faltas comunes". cución de la pena. Es necesario, por el contrario, comprender que la condena condicional exige un control sobre el liberado condicionalmente durante el período de prueba. Para esto se requiere organizar el Patronato, institución que no ha podido ser puesta en marcha en nuestro medio a pesar de haber sido prevista legislativa desde 1924.

Teniendo en cuenta que la aplicación de la condena condicional depende, fundamentalmente, de la personalidad del inculpado; que no tenemos establecimientos penales adecuados para la eficaz ejecución de las penas privativas de libertad; que nuestro mismo Código de procedimientos penales da la posibilidad de conceder la libertad provisional hasta en caso de penas de dos años de prisión; que en Derecho comparado existe la marcada tendencia a extender el campo de aplicación de la condena condicional, consideramos que una futura reforma penal deberá fijar en dos años el límite para la concesión de la condena condicional.

En consideración a que la condena condicional se impone en relación a la situación penal del agente, debe dejarse al juez la posibilidad de determinar la duración del período de prueba, para lo cual es necesario que el legislador establezca sólo un mínimum y un máximum.

Tanto el legislador como el juzgador deben reforzar el aspecto preventivo de la condena condicional. El primero, atenuando el carácter represivo de las causas de revocación y flexibilizando los requisitos para su concesión; en especial, el referente a que el inculpado no haya sufrido condena anterior nacional o extrarijera. El juzgador, teniendo en cuenta los fines reeducativos de la institución en el momento de aplicar las normas legales que la regulan.

Es evidente, que las modificaciones a realizar deben formar parte de una reforma profunda de nuestro sistema penal; reforma que no debe consistir "sólo en corregir el Derecho penal, sino en crear un mejor Derecho penal'. 